\title{
Alabama Forest Products and the Potential Impacts of FTAA Price Changes
}

\author{
Mostafa Malki \\ University of Texas - Brownsville \\ Henry Thompson \\ Auburn University \\ Osei-Agyeman Yeboah \\ North Carolina A\&T State University
}

\begin{abstract}
The Free Trade Area of the Americas FTAA will increase import competition for some forest product industries in Alabama but create export opportunities for others. Forest products loom large in the Alabama economy, both in terms of income and pollution. The present paper gauges the potential impacts of a range of price changes for forest products in an applied specific factors model of production. Pollution adjusts with forest product outputs. The potential impacts on outputs, capital returns, and pollution are substantial. Anticipated price changes also raise the wage and lower energy demand.
\end{abstract}

- JEL Classification:

- Key Words:

\section{Introduction}

The forest product industries in the Southeastern US and Alabama will be affected by the pending Free Trade Area of the Americas or FTAA. Alabama

*Corresponding address: Contact author: Henry Thompson, Department of Economics: 202 Comer Hall, Auburn University, AL 36849, U.S.A., Tel: 334-844-2910, Fax 5639, e-mail: thomph1@auburn.edu. ( $2010-$ Center for International Economics, Sejong Institution, Sejong University, All Rights Reserved. 
accounts for $11 \%$ of US paper products and the industry for $3 \%$ of state output. The present paper offers perspective on the potential economic impact of FTAA on production and income distribution with a simulated specific factors model of Alabama focused on forest products. Simulations examine the effects of a range of exogenous price changes on wages, capital returns, industrial outputs, and pollution from the forest product industries.

Paperboard and paper mill products are both net imports at present but FTAA will change their prices. The growing economies of Latin America will offer expanding export opportunities but there will be increased import competition for some forest products. Prestemon (1998b) predicts increased forest product exports to the Caribbean and the USDA Economic Research Service (1998a) predicts increased forest product trade.

Gains and losses will vary across industries similar to the effects of NAFTA. Boyd, Krutilla, and McKinney (1993) use a detailed computable general equilibrium model to predict NAFTA would have noticeable effects on particular US industries and regions. Hanson (1994) predicts NAFTA will hurt the Southeast but benefit states along the US border and in the Midwest. Marchant and Rupel (1993) predict little pressure on US agricultural prices in NAFTA. Thompson (1996) predicts substantial adjustment in Alabama manufacturing industries with a slight wage increase in an applied specific factors model similar to the present one. Wall (2000) shows that NAFTA has benefited manufacturing and services industries in Alabama.

Batyabal and Beladi (2001) conclude fears of unfair foreign advantage due to lax pollution laws are exaggerated. Tobey (2001) finds no evidence that environmental policies have affected patterns of production and trade in manufactures. Husted and Logsdon (2001) provide evidence that NAFTA has improved environmental policy and raised production cost in Mexico. The present model of forest products provides a detailed look at a link between trade policy and pollution.

Pulp and paper production involves bleach and release of stack emissions including hydrogen sulfides, nitric acids, and sulfuric acids as discussed by Smith (1997). Paper mills in Alabama use a daily average of 24 million gallons of water according to Ferguson (1998). The EPA "Cluster Rules" in effect since 1997 have led to elimination of chlorine and replacement by chlorine dioxide. Nevertheless the EPA Release Inventory (2003) reports the 16 mills in Alabama account for $65 \%$ of water pollution and $32 \%$ of air pollution in the state. Bailey and Newland 
(2000) show residents living close to these mills are disproportionately African American and local property values are depressed.

A full hemispheric model with final demands, industrial inputs, and forest resource endowments is well beyond the scope of the present model. Price changes, however, will fall within the wide range considered in the present simulations, and the present paper offers perspective on the range of adjustments in Alabama. The strength of the model is its ready application to other forest product regions and other issues in trade policy reform.

The section II develops the specific factors model and the section II develops the present application. The section IV derives the comparative static properties of the model, followed by sections projecting price impacts conclusions are in the section VII.

\section{A Brief Introduction to the Applied Specific Factors Model}

Details of the comparative static general equilibrium production model are in Jones and Scheinkman (1977) and Chang (1979). Production has constant returns, competitive pricing, and cost minimization but Thompson (2003) shows relaxing these assumptions has minimal impact on comparative static applications such as the present one. Capital is specific to each industry while labor and energy are mobile across industries in the present application. Thompson and Toledo (2001) apply the specific factors model to free trade in Bolivia.

Full employment is stated $v=A x$ where $v$ is the input vector, $A$ is a matrix of cost minimizing unit inputs, and $x$ is the output vector. Factor supplies are exogenous and perfectly inelastic. Differentiate to find $d v=x d A+A d x$ and introduce substitution terms $S_{i k}=\sum_{j} x_{j}\left(\delta a_{i j} / \delta w_{k}\right)$ that summarize adjustments in unit inputs $d A$ due to changing factor prices $w_{k}$. Unit inputs are homogeneous of degree zero in factor prices and are independent of output given homogeneity. Let $\mathrm{S}$ be the matrix of substitution terms and $d v=S d w+A d x$. Convert these changes into elasticity form to find

$$
v^{\prime}=\sigma w^{\prime}+\lambda x^{\prime}
$$

where' denotes percentage change, $\sigma$ is the matrix of cross price input substitution elasticities $\sigma_{i k}=\sum_{j} \lambda_{i j} a_{i j}{ }^{\prime} / w_{k}{ }^{\prime}$, and $\lambda$ is the matrix of industry shares $\lambda_{i j}=a_{i j} x_{j} / v_{i}$. Full employment implies the rows of $\lambda$ sum to 1 .

Competitive pricing implies $p=A^{T} w$ where $p$ is the vector of output prices and $w$ the factor price vector. The Alabama economy is assumed to be a price taker in 
all markets including paper products. Cost minimization implies the envelope condition $w d A^{T}=0$ leading to $d p=A^{T} d w$. Converting to elasticity form,

$$
p^{\prime}=\theta^{T} w
$$

where $\theta$ is the matrix of factor shares $\theta_{i j}=\sum_{i} a_{i j} w_{i} / p_{j}$. Competitive pricing implies the rows of $\theta^{T}$ sum to 1 .

Combining (1) and (2),

$$
\left[\begin{array}{ll}
\sigma & \lambda \\
\theta^{T} & 0
\end{array}\right]\left[\begin{array}{l}
w^{\prime} \\
x^{\prime}
\end{array}\right]=\left[\begin{array}{l}
v^{\prime} \\
p^{\prime}
\end{array}\right]=\left[\begin{array}{l}
0 \\
p^{\prime}
\end{array}\right]
$$

Simulation involves introducing a vector of exogenous price changes and solving for endogenous adjustments in factor prices and outputs. Note that factor endowments including forest resources in the endowment vector $v$ are constant. Changes in pollution are proportional to forest products.

\section{Factor Shares, Industry Shares, and Substitution}

Data on value added, employment, factor payments, and labor in manufacturing are from the US Census of Manufacturers. Energy data are from the Department of Energy, agricultural data from the USDA, and labor data for services from the Department of Labor.

Value added in services is derived as the residual of gross state product. There is no energy data for services and simulations assume the smallest manufacturing energy share $2 \%$ for services. Pollution is tied to production at the 3 -digit SIC industry level with data from the EPA Toxic Release Inventory (2003) as "release" for air pollution and "waste" for water pollution.

Table 1 shows total payments to labor L, capital K, and energy E with capital payment the residual of value added. Summing down a column in Table 1 gives industry value added.

The industries are Agriculture (A), Services (B), Converted paper products (C), Paper mills (P), pulp \& paperBoard (B), the rest of Manufacturing (M).

Table 2 reports the derived factor share matrix $\theta$. Value added in mills $\mathrm{P}$ is $\$ 1,762$ million and the labor share $\mathrm{L}$ is $578 / 1,762=32.8 \%$. The largest capital shares are in paperboard B and agriculture A followed by mills P. The forest products industries $\mathrm{C}, \mathrm{P}$, and $\mathrm{B}$ have larger capital shares than manufacturing $\mathrm{M}$. Labor shares are highest in services $\mathrm{S}$ and converted paper C. Manufacturing $\mathrm{M}$ has the highest energy share and paperboard B the highest labor share. 
Table 1. Factor Payment Matrix, (\$mil)

\begin{tabular}{cccccccc}
\hline & A & S & C & P & B & M & Total \\
& Agriculture & Services & Converted paper Paper mills & Paper board & Mfg & \\
\hline L & 126 & 43,019 & 119 & 578 & 269 & 20,375 & 64,486 \\
K & 447 & 29,815 & 126 & 978 & 1,046 & 24,886 & 57,298 \\
E & 103 & 1,486 & 57 & 206 & 174 & 14,366 & 16,392 \\
Total & 676 & 74,320 & 302 & 1,762 & 1,489 & 59,627 & 138,176 \\
\hline
\end{tabular}

Table 2. Factor Share Matrix $\theta$

\begin{tabular}{ccccccc}
\hline & A & S & C & P & B & M \\
\hline$L$ & .186 & .579 & .394 & .328 & .181 & .342 \\
$K$ & .661 & .401 & .417 & .555 & .702 & .417 \\
$E$ & .153 & .020 & .189 & .117 & .117 & .241 \\
\hline
\end{tabular}

Summing across rows in Table 1 gives total factor income. Mobility of labor and energy across industries implies their prices are equalized leading to the industry shares in Table 3. Total labor $\mathrm{L}$ income is $\$ 64,486$ million and less than $1 \%$ or $578 /$ $64,486=0.9 \%$ of labor is employed in mills P. About $2 / 3$ of labor is employed in services. Mills $\mathrm{P}$ and paperboard B each use just over $1 \%$ of energy, and manufacturing $\mathrm{M}$ consumes most of energy.

The Latin American countries in FTAA have abundant labor and low wages suggesting the US will import products using labor intensively as in Leamer (1984) and Bowen, Hollander, and Viane (1998). Factor intensities successfully predict the

Table 3. Industry Shares $\lambda_{i j}$

\begin{tabular}{ccccccc}
\hline & $\mathrm{A}$ & $\mathrm{S}$ & $\mathrm{C}$ & $\mathrm{P}$ & $\mathrm{B}$ & $\mathrm{M}$ \\
\hline$L$ & .002 & .667 & .002 & .009 & .004 & .316 \\
$K$ & .008 & .520 & .002 & .017 & .018 & .434 \\
$E$ & .006 & .091 & .003 & .013 & .011 & .876 \\
\hline
\end{tabular}

Table 4. Factor Intensities

\begin{tabular}{cccc}
\hline & $K / E$ & $K / L$ & $E / L$ \\
\hline $\mathrm{A}$ & 4.34 & 3.55 & 0.82 \\
$\mathrm{~S}$ & 20.1 & 0.69 & 0.04 \\
$\mathrm{C}$ & 2.21 & 1.06 & 0.48 \\
$\mathrm{P}$ & 4.75 & 1.69 & 0.36 \\
$\mathrm{~B}$ & 6.01 & 3.89 & 0.65 \\
$\mathrm{M}$ & 1.73 & 1.22 & 0.71 \\
\hline
\end{tabular}


direction of trade in natural resource industries.

Table 4 reports factor intensities for pairs of inputs. Industry $j$ uses factor $i$ intensively relative to industry $h$ and factor $k$ if $a_{i j} / a_{i h}>a_{k j} / a_{k h}$. The labor share in industry $j$ is $\theta_{L j}=w L_{j} / x_{j}$ where value added is $x_{j}=p_{j} x_{j}$ and $w$ is the wage. The capital factor share is similar and the ratio of capital to labor factor shares is $q_{K j} / q_{L j}=r a_{K j} /$ $w_{L} a_{L j}$ implying $\theta_{K j} / \theta_{L j}=\left(a_{K j} / a_{L j}\right)\left(r_{j} / w\right)$.

The most labor intensive industry in manufacturing is converted paper $\mathrm{C}$ while paperboard B is capital intensive relative to both labor and energy. The suggestion is that converted paper $\mathrm{C}$ will face import competition from labor cheap Latin America while paperboard B would face little competition. Transport costs and the location of forests will be critical, however, to the pattern of production and trade. Mills $\mathrm{P}$ will remain located close to forests. Converted paper $\mathrm{C}$ seem likely to face falling prices with import competition. Expanded export opportunities seem more likely for mills $\mathrm{M}$ and paperboard B. Model simulations assume a range of price changes.

Substitution elasticities describe adjustment in the cost minimizing input of an input due to a change in price of another as developed by Jones (1965) and Takayama (1982). The cross price elasticity between the input of factor $i$ and the payment to factor $k$ in sector $j$ is $E_{i j}{ }^{k}=\theta_{k j} S_{i j}{ }^{k}$ where $S_{i j}{ }^{k}$ is the Allen (1938) partial elasticity of substitution. Cobb-Douglas production implies $S_{i j}^{k}=1$ and constant elasticity of substitution CES scales the Allen partial elasticity accordingly. Linear homogeneity of cost functions implies $\Sigma_{\mathrm{k}} \mathrm{E}_{i j}^{\mathrm{k}}=0$ and own price elasticities $\dot{E}_{i j}$ are derived as the negative sum of cross price elasticities.

Aggregate substitution elasticities are weighted average of cross price elasticities, $\sigma_{i k}=\Sigma_{j} \lambda_{i j} E_{i j}^{k}=\Sigma_{j} \lambda_{i j} \theta_{k j} S_{i j}^{k}$. Derived Cobb-Douglas elasticities are in Table 5. Changes in industry capital prices $r_{j}$ have no effect on capital inputs in other industries. Cobb-Douglas provides a reasonable reference point and simulations with constant elasticity of substitution CES are discussed. As an example $\mathrm{CES}=0.5$ implies elasticities half as large as those in Table 5. In the literature on estimating substitution elasticities, there is some variation in substitution as well as instances of weak complements for energy and capital. Thompson (1995) finds factor intensity can be expected to play a more critical role than substitution in model simulations.

The largest own substitution elasticity is for the price of energy $e$ but all are inelastic and the smallest is for paperboard capital $r_{B}$. The own wage elasticity is fairly large, every $1 \%$ increase in $w$ decreasing labor input per unit of output across 
Table 5. Substitution Elasticities $s$

\begin{tabular}{ccccccccc}
\hline & $w$ & $e$ & $r_{A}$ & $r_{S}$ & $r_{C}$ & $r_{P}$ & $r_{B}$ & $r_{M}$ \\
\hline$\hat{a}_{L}$ & -.682 & .092 & .001 & .399 & .001 & .004 & .001 & .184 \\
$\hat{a}_{E}$ & .361 & -.938 & .002 & .054 & .002 & .006 & .003 & .510 \\
$\hat{a}_{A}$ & .186 & .152 & -.339 & 0 & 0 & 0 & 0 & 0 \\
$\hat{a}_{S}$ & .579 & .020 & 0 & -.599 & 0 & 0 & 0 & 0 \\
$\hat{a}_{C}$ & .394 & .189 & 0 & 0 & -.583 & 0 & 0 & 0 \\
$\hat{a}_{P}$ & .328 & .117 & 0 & 0 & 0 & -.445 & 0 & 0 \\
$\hat{a}_{B}$ & .181 & .117 & 0 & 0 & 0 & 0 & -.298 & 0 \\
$\hat{a}_{M}$ & .342 & .241 & 0 & 0 & 0 & 0 & 0 & -.583 \\
\hline
\end{tabular}

industries by $0.7 \%$. Own capital elasticities in converted paper $r_{C}$ and manufacturing $r_{M}$ are relatively high and similar to services $r_{S}$. Own capital elasticities are smaller than own labor and energy elasticities. Changes in the wage $w$ induce more adjustment in capital inputs than vice versa. Changes in the price of energy $e$ generate less capital substitution than changes in the wage $w$.

\section{Comparative Static Properties of the Forest Products Model}

Comparative static elasticities of factor prices with respect to changes in product prices are found by inverting system (3). Table 6 indicates some factors benefit while others lose with any price change and effects are uneven. A higher price raises the return to industrial capital but lowers other capital returns due to the departure of labor and energy from those industries. Price changes affect returns to specific capitals $r_{j}$ much more than the wage $w$ or the price of energy $e$. These comparative static effects of price changes on factor prices are the same for any degree of CES substitution as shown by Thompson and Toledo (2001).

Every $1 \%$ increase in the price of converted paper $p_{C}$ would have very minor effects on the wage $w$ and the price of energy $e$ but increase its capital return $r_{B}$ by $2.4 \%$. The higher price draws labor from other sectors but the effect is small because the industry is small and the least labor intensive. Price changes for pulp \& paperboard products $p_{B}$ and mills $p_{P}$ have similar smaller effects.

Every $1 \%$ increase in the price of services $p_{S}$ would raise the wage $w$ by $0.8 \%$ and its capital return $1.4 \%$, the large wage effect due to the large size of the sector and its high labor intensity. Every $1 \%$ increase in the price of manufactures $p_{M}$ leads to an elastic $1.3 \%$ impact on the price of energy $e$ due to its high energy intensity and share. Price changes in the large service sector $p_{S}$ have the strongest 
Table 6. Comparative Static Price Elasticites of Factor Prices

\begin{tabular}{ccccccc}
\hline & $p_{A}$ & $p_{S}$ & $p_{C}$ & $p_{P}$ & $p_{B}$ & $p_{M}$ \\
\hline$w$ & 0.001 & 0.782 & 0.002 & 0.005 & 0.001 & 0.211 \\
$e_{E}$ & 0.003 & -0.294 & 0.004 & 0.009 & 0.005 & 1.272 \\
$r_{A}$ & 1.512 & -0.152 & -0.001 & -0.003 & -0.001 & -0.352 \\
$r_{S}$ & -0.001 & 1.380 & -0.002 & -0.007 & -0.001 & -0.368 \\
$r_{C}$ & -0.002 & -0.605 & 2.395 & -0.009 & -0.003 & -0.776 \\
$r_{P}$ & -0.001 & -0.400 & -0.002 & 1.797 & -0.001 & -0.393 \\
$r_{B}$ & -0.001 & -0.153 & -0.001 & -0.003 & 1.424 & -0.266 \\
$r_{M}$ & -0.002 & -0.471 & -0.004 & -0.009 & -0.003 & 1.490 \\
\hline
\end{tabular}

factor price effects. Among the forest products industries the paper mill price $p_{P}$ has slightly larger impacts.

Table 7 reports price elasticities of outputs along the production frontier. A ceteris paribus higher price raises that output by attracting labor and energy from other industries whose outputs fall. Output elasticities are generally inelastic with the largest own effect for converted paper $x_{C}$ where every $1 \%$ increase in price raises output by $1.4 \%$. Mills $x_{P}$ has a larger own elasticity than manufacturing $x_{M}$ while pulp \& paperboard $x_{B}$ has a slightly smaller own elasticity. The service $x_{S}$ own output elasticity is the smallest due to the large size of the sector making it more difficult to attract labor and energy from the rest of the economy.

\section{Potential Factor Price Adjustments in FTAA}

Factor price adjustments are found multiplying the matrix of factor price elasticities in Table 6 by an exogenous vector of price changes. Simulated price changes range from $\pm 10 \%$ with increases for services $p_{S}$, decreases for manufacturing $p_{M}$, and a variety of changes for forest product prices in Tables 8,9 , and 10 .

Table 7. Comparative Static Price Elasticities of Outputs

\begin{tabular}{ccccccc}
\hline & $p_{A}$ & $p_{S}$ & $p_{C}$ & $p_{P}$ & $p_{B}$ & $p_{M}$ \\
\hline$x_{A}$ & 0.512 & -0.152 & -0.001 & -0.003 & -0.001 & -0.352 \\
$x_{S}$ & -0.001 & 0.380 & -0.002 & -0.007 & -0.001 & -0.368 \\
$x_{C}$ & -0.002 & -0.605 & 1.395 & -0.009 & -0.003 & -0.776 \\
$x_{P}$ & -0.001 & -0.400 & -0.002 & 0.797 & -0.001 & -0.393 \\
$x_{B}$ & -0.001 & -0.153 & -0.001 & -0.003 & 0.424 & -0.266 \\
$x_{M}$ & -0.002 & -0.471 & -0.004 & -0.009 & -0.003 & 0.490 \\
\hline
\end{tabular}


Table 8. FTAA Adjustments with $\pm 5 \%$ Price Changes

\begin{tabular}{|c|c|c|c|c|c|c|c|c|c|c|c|}
\hline \multirow[t]{3}{*}{$\%$} & \multicolumn{2}{|c|}{ Price } & \multicolumn{4}{|c|}{ Factor price } & \multicolumn{2}{|c|}{ Output } & \multicolumn{2}{|l|}{$\begin{array}{l}\text { Release } \\
\text { (Tons) }\end{array}$} & \multirow[t]{2}{*}{$\begin{array}{l}\text { Waste } \\
\text { (Tons) }\end{array}$} \\
\hline & & & $\mathrm{w}$ & 2.9 & 2.8 & & & & & & \\
\hline & & & $\mathrm{e}$ & -7.7 & -7.9 & & & & & & \\
\hline A & 2 & 2 & $r_{A}$ & 4.0 & 4.1 & $\mathrm{x}_{\mathrm{A}}$ & 2.0 & 2.1 & & & \\
\hline $\mathrm{S}$ & 5 & 5 & $\mathrm{r}_{\mathrm{S}}$ & 8.7 & 8.8 & $\mathrm{x}_{\mathrm{S}}$ & 3.7 & 3.8 & & & \\
\hline $\mathrm{C}$ & 5 & -5 & $r_{C}$ & 12.8 & -11.1 & $\mathrm{x}_{\mathrm{C}}$ & 7.8 & -6.1 & 305 & -238 & $2,981-2,328$ \\
\hline $\mathrm{P}$ & 5 & -5 & $r_{P}$ & 8.9 & -9.0 & $\mathrm{x}_{\mathrm{P}}$ & 3.9 & -4.0 & 143 & -146 & $1,215-1,238$ \\
\hline B & 5 & -5 & $r_{B}$ & 7.7 & -6.5 & $\mathrm{x}_{\mathrm{B}}$ & 2.7 & -1.5 & 357 & -206 & $2,286-1,319$ \\
\hline M & -5 & -5 & $r_{M}$ & -9.9 & -9.7 & $\mathrm{x}_{\mathrm{M}}$ & -4.9 & -4.7 & & & \\
\hline Total & & & & & & & & & 805 & -590 & $6,482-4,885$ \\
\hline
\end{tabular}

The first column in Table 8 simulates baseline 5\% price increases except the $2 \%$ increase for agriculture $p_{A}$ and the $-5 \%$ decline for manufactures $p_{M}$, a cautiously optimistic scenario for forest products. The wage $w$ increases $2.9 \%$ while the energy price $e$ falls by $-7.7 \%$. The higher wage is due primarily to the higher price $p_{S}$ in the large labor intensive service sector. Capital return effects are magnified from underlying price changes. The return to capital in manufacturing $r_{M}$ falls by 9.9\% and there are large positive effects on capital returns in converted paper $r_{C}$ $12.8 \%$, mills $r_{P} 8.9 \%$, and paperboard $r_{B} 6.5 \%$.

The second column in Table 8 presents a baseline pessimistic scenario with symmetric price declines for the three forest products. The two columns in Table 8 provide reasonable opposing scenarios for paper products industries. The wage $w$ and price of energy $e$ changes are nearly identical to the first column but declining forest product prices have large negative impacts on their capital returns, $-11.1 \%$ for converted paper $r_{C},-9.0 \%$ for mills $r_{B}$ and $-6.5 \%$ for paperboard $r_{B}$. The service sector attracts labor and energy but energy demand falls since services use little energy.

Table 9 separates capital intensive paperboard from the other two paper products industries on the assumption its output would be exported with a higher price $p_{B}$. The price changes in services and manufacturing are moderated to $3 \%$ and $-2 \%$. The second column considers a price decline in agriculture of $-2 \%$ and a price increase for mills $p_{P}$.

The wage $w$ is tied closely to services increasing only $1.9 \%$ shadowing the price of services. The decrease in the price of energy $p_{e}$ is dampened due to the smaller price decrease in manufacturing and the mixed changes in paper products. The return to capital in paperboard $r_{B}$ rises $7.2 \%$ with the increase in $p_{B}$ in either 
Table 9. Capital Intensive Paperboard Exports

\begin{tabular}{|c|c|c|c|c|c|c|c|c|c|c|c|c|}
\hline \multirow[t]{2}{*}{$\%$} & \multicolumn{2}{|c|}{ Price } & \multicolumn{4}{|c|}{ Factor price } & \multicolumn{2}{|c|}{ Output } & \multicolumn{2}{|l|}{$\begin{array}{c}\text { Release } \\
\text { (Tons) }\end{array}$} & \multicolumn{2}{|l|}{$\begin{array}{l}\text { Waste } \\
\text { (Tons) }\end{array}$} \\
\hline & & & $\mathrm{W}$ & 1.9 & 1.9 & & & & & & & \\
\hline & & & $\mathrm{e}$ & -3.5 & -3.4 & & & & & & & \\
\hline A & 2 & -2 & $\mathrm{r}_{\mathrm{A}}$ & 3.3 & -2.8 & $\mathrm{x}_{\mathrm{A}}$ & 1.3 & -0.8 & & & & \\
\hline $\mathrm{S}$ & 3 & 3 & $r_{S}$ & 4.9 & 4.9 & $\mathrm{x}_{\mathrm{S}}$ & 1.9 & 1.9 & & & & \\
\hline $\mathrm{C}$ & -5 & -5 & $r_{C}$ & -12.2 & -12.3 & $\mathrm{x}_{\mathrm{C}}$ & -7.2 & -7.3 & -283 & -287 & $-2,769$ & $-2,800$ \\
\hline$P$ & -5 & 5 & $r_{P}$ & -9.4 & 8.6 & $\mathrm{x}_{\mathrm{P}}$ & -4.4 & 3.6 & -160 & 130 & $-1,358$ & 1,105 \\
\hline B & 5 & 5 & $r_{B}$ & 7.2 & 7.2 & $\mathrm{x}_{\mathrm{B}}$ & 2.2 & 2.2 & 296 & 293 & 1,898 & 1,875 \\
\hline M & -2 & -2 & $r_{M}$ & -4.4 & -4.4 & $\mathrm{x}_{\mathrm{M}}$ & -2.4 & -2.4 & & & & \\
\hline Total & & & & & & & & & -147 & 136 & $-2,229$ & 180 \\
\hline
\end{tabular}

scenario. The return to capital $r_{P}$ in mills strongly reflects the two price changes. The return $r_{A}$ to agricultural capital including land swings with the price change but there are no other noticeable effects due to agriculture's small size.

Table 10 represents a radical price scenario with prices changes in manufacturing and forest products of $\pm 10 \%$. The price of capital intensive paperboard $p_{B}$ rises while other forest product prices fall in the second column. The wage increases substantially due to the $10 \%$ increase in the price of services $p_{S}$. Projected decreases in the price of energy $e$ are large due to the $-10 \%$ decrease in manufacturing $p_{M}$. Adjustments in returns to capital are substantial, over twice the size of the price decline in converted paper $r_{C}$.

\section{Potential Output and Pollution Adjustments in FTAA}

Output adjustments in Tables 8 through 10 are found multiplying output Table 10. Radical Price Scenarios

\begin{tabular}{|c|c|c|c|c|c|c|c|c|c|c|c|c|}
\hline \multirow[t]{3}{*}{$\%$} & \multicolumn{2}{|c|}{ Price } & \multicolumn{4}{|c|}{ Factor Price } & \multicolumn{2}{|c|}{ Output } & \multicolumn{2}{|l|}{$\begin{array}{l}\text { Release } \\
\text { (Tons) }\end{array}$} & \multicolumn{2}{|l|}{$\begin{array}{l}\text { Waste } \\
\text { (Tons) }\end{array}$} \\
\hline & & & W & 5.8 & 5.7 & & & & & & & \\
\hline & & & e & -15.5 & -15.7 & & & & & & & \\
\hline A & 5 & 5 & $\mathrm{r}_{\mathrm{A}}$ & 9.5 & 9.6 & $\mathrm{x}_{\mathrm{A}}$ & 4.5 & 4.6 & & & & \\
\hline $\mathrm{S}$ & 10 & 10 & $\mathrm{r}_{\mathrm{S}}$ & 17.4 & 17.6 & $\mathrm{x}_{\mathrm{S}}$ & 7.4 & 7.6 & & & & \\
\hline $\mathrm{C}$ & 10 & -10 & $\mathrm{r}_{\mathrm{C}}$ & 25.5 & -22.2 & $\mathrm{x}_{\mathrm{C}}$ & 15.5 & -12.2 & 610 & -479 & 5,962 & $-4,679$ \\
\hline $\mathrm{P}$ & 10 & -10 & $r_{P}$ & 17.9 & -18.0 & $\mathrm{x}_{\mathrm{P}}$ & 7.9 & -8.0 & 287 & -293 & 2,429 & $-2,482$ \\
\hline $\mathrm{B}$ & 10 & 10 & $r_{B}$ & 15.3 & 15.4 & $\mathrm{x}_{\mathrm{B}}$ & 5.3 & 5.4 & 713 & 724 & 4,570 & 4,639 \\
\hline M & -10 & -10 & $r_{M}$ & -19.8 & -19.5 & $\mathrm{x}_{\mathrm{M}}$ & -9.8 & -9.5 & & & & \\
\hline Total & & & & & & & & & 1,610 & -48 & 12,961 & $-2,522$ \\
\hline
\end{tabular}


elasticities in Table 7 by vectors of projected price changes. The $5 \%$ price changes in baseline Table 8 affect paper product outputs in the same direction and typically by a slightly smaller percentage except for converted paper $x_{C}$. Manufacturing output $x_{M}$ follows its price change with near unit output elasticity while the increase in services output $x_{S}$ is somewhat smaller than its price increase. Agricultural output $x_{A}$ has near unit elasticity with a $2 \%$ price increase. The downside output effects with the pessimistic scenario in the second column of Table 8 are slightly larger for converted paper $x_{C}$.

The associated changes in pollution for forest products industries depend on the size and direction of output adjustments. The $5 \%$ price increases in the first column of Table 8 generate increases of 805 tons of air and 6,482 tons of water pollution. Percentage pollution changes are identical to outputs assuming constant technology.

With falling outputs in the pessimistic column of Table 8 the associated reductions in pollution for are smaller for converted paper and paperboard but larger for mills. Total net changes are a decrease of -590 tons for release and $-4,885$ tons for waste.

In Table 9 changes in pollution are smaller due to the offsetting output adjustments. In the second column pollution increases with mills $\mathrm{P}$ and paperboard B outputs but is offset almost exactly by the decrease in converted paper C.

The radical price increases in Table 10 generate very large changes in pollution, totaling 12,691 tons for waste and for 1,610 tons release. Price decreases in mills P and paperboard B moderate increases in the second column.

Constant elasticity of substitution CES production scales the output and pollution adjustments in Tables 8 through 10. For instance CES $=0.5$ implies predicted adjustments in output and associated pollution are half as large. Estimates of input substitution in the literature are typically inelastic in the range from 0.2 to 1 suggesting the output and pollution adjustments in Tables 8 through 10 are upper limits.

\section{Conclusion}

The present specific factors model of Alabama projects adjustments in income distribution, outputs, and pollution due to a range of changing prices for forest product industries in the FTAA. The range of simulated adjustments suggests noticeable impacts including a higher wage, falling energy demand, increased 
capital returns in agriculture and services, and lower capital returns in manufacturing.

Prices in the each of three forest product industries are difficult to predict, and may increase with export demand or fall with import competition. Output and capital returns follow industry price changes, and the associated changes in pollution may be substantial.

Increases in pollution from particular forest products industries may be offset by decreases in others depending on the evolving pattern of competition in the hemisphere. Increases in air and water pollution from capital intensive paperboard production may be offset by decreases from paper mills and converted paper products. While the present applied specific factors model does not offer an unambiguous bottom line it does provide a gauge for the size of potential changes in pollution.

Received 7 October 2009, Revised 19 November 2009, Accepted 25 November 2009

\section{References}

Allen, R.G.D.(1938), Mathematical Analysis for Economist, MacMillan, 1938.

Bailey, Conner and Christopher Newland(2000), "Toxics, Environmental Justice, and Alabama's Pulp and Paper Industry", Paper Presented at 2000 Meetings of Rural Sociological Society, Washington, DC, August 2000.

Batyabal, Amitrajeet and Hamid Beladi(2001), The Economics of International Trade and the Environment, Washington: Lewis Publishers.

Bowen, Harry P., Abraham Hollander, and Jean-Marie Viaene(1998), Applied International Trade Analysis, London: MacMillian, 287.

Boyd, R.G., K. Krutilla, and J, McKinney(1993), "The Impact of Tariff Liberalization between the United States and Mexico: an Empirical Analysis", Applied Economics, 22, p. 81-89.

Chang, W.W.(1979), "Some Theorems of Trade and General Equilibrium with Many Goods and Factors", Econometrica, 47, pp. 709-726.

EPA Toxic Release Inventory (2003), webpage.

Ferguson, Kelly II(1998), "EPA Regulatory Reinvention Program Offers Flexibility for Weyco Flint River." PAPER, 72(8), pp. 65-68.

Hansen, N.(1994), "NAFTA: Implications for US Regions", The Survey of Regional Literature, pp. 4-22.

Husted, Bryan and Jeanne Logsdon(2001), “The Impact of NAFTA on Mexico's Environmental Policy", in The Economics of International Trade and Environment, edited by Batyabal and Beladi, Lewis Publishers, Washington DC. 
Jones, Ronald W.(1965), "The Structure of Simple General Equilibrium Models", Journal of Political Economy, pp. 557-572.

Jones, R.W. and J.A. Scheinkman(1977), "The Relevance of the Two-Sector Production Model in Trade Theory", The Journal of Political Economics, 15, pp. 65-99.

Leamer, E.(1984), Sources of Comparative Advantage: Theory and Evidence, Cambridge: The MIT Press.

Marchant, M.A. and F.J. Rupel(1993), "The Impacts of Lesser Developed Countries on Southern Region Agricultural Exports", Agricultural and Resource Economic Review, 22, pp. 71-87.

Prestemon, J. P.(1998), "The Effects of NAFTA and an FTAA on US Exports of Hardwood Forest Products", Proceeding of the Annual Hardwood Symposium of the Hardwood Research Council, The National Hardwood Lumber Association 26, pp. 35-44.

Smith, Danna(1997), "Chipping Forests \& Jobs; A Report of the Economic and Environmental Impacts of Chip Mills in the Southeast", Brevard, NC: The Dogwood Alliance.

Takayama, Akira(1982), "On the Theorems of General Competitive Equilibrium of Production and Trade - A Survey of Some Recent Developments in the Theory of International Trade", Kieo Economic Studies, pp. 1-37.

Thompson, Henry(1996), "NAFTA and Industrial Adjustment: Specific Factor Model of Production in Alabama", Growth and Change, Winter, pp. 3-28.

Thompson, Henry(1995), "Factor Intensity versus Factor Substitution in a Specified General Equilibrium Model", Journal of Economic Integration 10, pp. 283-297.

Thompson, Henry(1996), "NAFTA and Industrial Adjustment: a Specific-Factors Models of Production", Growth and Change, 27, pp. 3-28.

Thompson, Henry(2003), Robustness of the Stolper-Samuelson Factor Intensity Price Link, in

Handbook of International Trade, edited by Kwan Choi and James Harrigan, Blackwell.

Thompson, Henry and Hugo Toledo(2001), "Bolivia and South American Free Trade", International Trade Journal Spring, pp. 113-126.

Tobey, James(2001), "The Effects of Domestic Environmental Policies on Patterns of World Trade: an Empirical Test", in The Economics of International Trade and the Environment, Edited by Amit Batyabal and Hamid Beladi, Lewis Publishers.

US Forest Service(2001), Southern Forest Resource Assessment Chapter 13: Timber Products Supply and Demand, Jeffrey P. Prestemon and Robert C. Abt, webpage

US Census of Manufacturers(1997), Manufacturing by Subsector, webpage.

US Department of Agriculture(1999), Farm Income and Costs: Farm Income Forecasts, webpage.

USDA/ERS(1998a), "Free Trade in the Americas: Potential Advantages for US Agriculture", Agricultural Outlook, April 1998: p. 11-15.

US Department of Energy(1998), Expenditures for Purchased Energy Sources, 1998; National Data and Regional Totals, Webpage. 
US Department of Labor(1997), Average Hourly Earnings of Production or Nonsupervisoty Workers by Industry, in current and constant (1982) Dollars, webpage.

Wall, Howard(2000), "NAFTA and the Geography of North American Trade", Federal Reserve Bank of St Louis Working Paper. 